\title{
Women creators of Latin American electronic literature: a geographical overview*
}

\section{Mulheres da América Latina que criam literatura digital: uma visão geográfica geral}

\author{
Nohelia Meza ${ }^{a}$ \\ a University of Leeds, United Kingdom - n.meza@leeds.ac.uk
}

Keywords:

Electronic Literature. Women. Latin American. Digital Creation.

Palavras-chave: Literatura Eletrônica. Mulheres. América Latina. Criação Digital.

\begin{abstract}
In this article, I present a geographical overview of women creators of Latin American electronic literature. My research is based on an initial survey of works included in different international databases and collections. A series of interviews with the artists was conducted as part of the research. Additionally, I have created a histogram with a dataset of 43 women creators in order to identify potential relations between their country of birth, the year of creation of their first work and the technological tools they used. The overview has shed light on the first women translators of electronic literature in Latin America (English into Portuguese) and on the first e-lit works written in languages other than Spanish and Portuguese (e.g. English and French). Overall, the work presented here acts as a first attempt towards documenting the contribution of Latin American women to electronic literature.
\end{abstract}

Resumo: Neste artigo, faço uma apresentação das mulheres criadoras de literatura eletrônica latino-americana, a partir de sua localização geográfica e baseando-me em obras incluídas em diferentes bancos de dados e coleções internacionais, bem como uma série de entrevistas com a maioria dos artistas foi realizada como parte da pesquisa. Isso possibilitou a criação de um histograma que apresenta informações a respeito de 43 mulheres criadoras e identifica as relações entre o país de nascimento, o ano de criação do primeiro trabalho publicado e as ferramentas tecnológicas utilizadas. A partir dessa abordagem, pôde-se identificar as primeiras mulheres latinoamericanas tradutoras de literatura eletrônica do inglês para o português e os primeiros trabalhos escritos em outros idiomas (inglês e francês), além do espanhol e do português. Trata-se, assim, de um trabalho que se desenha como uma primeira tentativa de documentar a contribuição das mulheres latino-americanas para a literatura eletrônica.

\footnotetext{
* This work is part of the project "Towards a Digital Rhetoric of Latin American Works of Electronic Literature” supported by CONACYT-México (2019-000029-01EXTV).
} 


\section{Introduction}

Latin American and Latino representation in the Electronic Literature Organization's collections of such works - highly influential points of reference in the field internationally - has improved considerably over the three volumes curated thus far: from 3 works in the first collection (ELC1, 2006) to 7 in the second (ELC2, 2011), to 13 in the third (ELC3, 2016)..$^{\dagger}$ Furthermore, contrary to what might be "typical" expectations about the presence of women creators in this field, female writers/artists/programmers made up 67\% of the "authorship" of Latin American and Latino works in the first collection, and $43 \%$ of such works in the third. ${ }^{\ddagger}$ What is worth taking from these sample statistics is that women creators of electronic literature have been acknowledged as producing highly innovative works by others in the field, and, although the collections do not present materials in chronological order of creation, closer examination of the works themselves indicates that Latin American and Latina women creators of electronic literature have been making their presence felt strongly since the very early days ${ }^{\S}$.

While some attention has recently been paid to women creators of electronic literature (MENCÍA, 2017; PITMAN, 2019), ${ }^{* *}$ there is still no significant research available that targets the contributions of Latin American women creators specifically. This overview is intended, therefore, to be a first step in this direction, and an invitation to others to fill this gap. Though archival work has recently begun in certain countries (Chile and

\footnotetext{
$\dagger$ The ELC1 (2006) contained works by Giselle Beiguelman and Helga Stein; Loss Pequeño Glazier; and María Mencía. The ELC2 (2011) works by Doménico Chiappe and Andreas Meier; Chico Marinho; Mark Marino; Jaime Alejandro Rodríguez; Stephanie Strickland and Cynthia Lawson Jaramillo; Stephanie Strickland, Cynthia Lawson Jaramillo and Paul Ryan; and Eugenio Tisselli. The ELC3 (2016), works by José Aburto; Electronic Disturbance Theater/BANG Lab; Micha Cárdenas; Belén Gache; Rodolfo JM, Leonardo Aranda, Gabriella Gordillo et al.; Augusto Marquet and Gabriel Wolfson; Santiago Ortiz; Jaime Alejandro Rodriguez; Alckmar Luiz dos Santos, Chico Marinho et al.; Eugenio Tisselli; Yolanda de la Torre, Raquel Gómez and Mónica Nepote; Ana María Uribe; and Karen Villeda and Denise Audirac. In compiling this list, I have taken into account the nationality/ethnicity of authors as well as the thematic focus or fictional location of works - it is thus as generous as possible in its assessment of "Latin American-ness".

$¥$ It is only the second collection that is disappointing in this regard: the only works that might be said to have any female Latin American "authorship" are those which include digital artist and programmer Cynthia Lawson Jaramillo.

$\S$ An overview of Latina women creators of electronic literature in the USA is not included in this article but will be addressed in a future work.

** Edited by María Mencía, \#WomenTechLit (2017) explores the creative work of women in the international field of electronic literature over the past several decades, bringing together the work of 28 scholars and creators. Written by Thea Pitman, "Latin American Electronic Literature created by women" (2019) constitutes the first study of Latin/o American women's contributions to the e-lit field.
} 
Brazil) $)^{\dagger \dagger}$ still there is much to be done in terms of genre categorisation of the works ${ }^{\dagger+}$. My overview of women creators of Latin American electronic literature here is based on an initial survey of both the works included in the Electronic Literature Organization Collections and those included in the ELMCIP Electronic Literature Knowledge Base (2010-) hosted and maintained by the University of Bergen, such as Luciana Gattass' Brazilian Electronic Literature Collection (2012) and Maya Zalbidea's collection Spanish Language Electronic Literature (2014). As well as those in other collections such as the Spanish project Ciberia (2014-), the "literature section" of the Cultura Digital Chile project (2016), the Mexico City-based Centro de Cultura Digital's Eliterature collection (2018), the Atlas de Literatura Digital Brasileira (2019-), and the Argentinian Itaú Anthology of Digital Stories (2018-2019). Nonetheless, through a deliberate expansion of the typical parameters used to define electronic literature ${ }^{\S}$, I have also chosen to include other female writers/artists/programmers who have not (yet) been mentioned in such collections and databases. Additionally, I have created a histogram with a dataset of 43 women creators in order to identify potential relations between their country of birth, the year of creation of their first work and the technological tools they used.

\section{Geographical Overview}

\subsection{Argentina's kinetic poetry and intertextual experimentation}

E-literature has "nodes" of feverish activity in certain Latin American countries, Argentina, Brazil, Chile, Colombia and Mexico being the most obvious. Most of the Latin American women creators included in these recent, global databases of electronic literature fall into the loose definition of e-poets. For this reason, a further study on the development of genres of practice of electronic literature in the region is needed. One of the earliest to make their mark in this emerging field was Ana María Uribe (Argentina,

\footnotetext{
it The research projects are the following: "Cartography of Latin American Digital Literature" (CONICYT, 2018-2021) led by Carolina Gainza (Diego Portales University, Chile) and "Repositório da Literatura Digital Brasileira" (CNPq 2018-2022) led by Rejane Rocha (UFSCar, Brazil).

$\$$ In 2018, the Latin American Electronic Literature Network (litElat) opened its call for submissions for electronic literary works from Latin America and the Caribbean, the aim is to create the first Anthology of Latin American Electronic Literature (edited by Claudia Kozak (AR), Leonardo Flores (PR) and Rodolfo Mata (MX) to be launched in late 2020.

$\S \S$ Electronic literature is defined as "new forms and genres of writing that explore the specific capabilities of the computer and network - literature that would not be possible without the contemporary digital context" (S. Rettberg, 2019, p. 2).
} 
1944-2004), who worked with visual and kinetic poetry. Uribe was a pioneer in remediating her own poetry, over time she moved from creating non-digital Tipoemas [Typoems] (1968-1969) (Olivetti Lettera 22) focusing on typescript and layout in the $1960 \mathrm{~s}$, to digitally remediated versions of the same, as well as the creation of Anipoemas [Anipoems] (1997-2003) (HTML, web-based and CD-ROM) or digitally animated poems, from the 1990s onwards. The performative and playful lettrism of her e-poetry is known for the aesthetic combination of letters, space, motion, rhythm, repetition and colour. A recurring theme in her work is the strong relationship between gender and nature as seen in the tipoemas "Catarata" [Waterfall] (1968), "Otoño" [Autumn] (1968), "Se largó" [It's raining] (1969) (Fig. 1a), and the anipoemas: "Hojas rojas secas" [Dry Red Leaves] (1997), "Primavera" [Spring] (1999), "Invierno" [Winter] (1999); something that would subsequently be explored by other Latin American women creators. Uribe's poetry is currently archived in artist Jim Andrews' website Vispo (1996-2020) and can be read in English, Finnish and Spanish, being amongst the first Latin American e-poets to be translated into other languages.

Another key figure with a long career in the field is Belén Gache (Argentina, 1960). Gache is a prolific creator who started producing works of "expanded and experimental literature" - interactive works, video poems and multimedia narratives - for circulation and consumption online from the mid-1990s via the Fin del Mundo El arte actual desde Argentina website (1995-2009) (HTML, web-based). This project was founded by Belén Gache, Jorge Haro, Gustavo Romano, and Carlos Trilnick in Buenos Aires in 1995. In fact, she published her first two digital works, Purpúreas Orquídeas: poemas cíclicos (1996) (HTML, web-based) (Fig. 1b) and Mariposa-Libro (1999-2001) (HTML, web-based, CD-ROM) as a part of this project. The first work is composed of interactive orchids that tell women's stories by using figurative language related to nature to describe their feelings and emotions. It is important to mention that the texts included in Purpúreas Orquídeas belonged to Gache's first printed novel Luna India (1994). The creative oscillation between print and digital must be underlined in her early works. For instance, Mariposa-Libro, an interactive narrative constructed of literary quotations from works by Julio Cortázar, Rubén Darío, José Lezama Lima, Jacques Lacan, Marcel Proust, Arthur Rimbaud that associate butterflies with women, 
flowers, gardens, colours, water, spring and dreams, was later incorporated in CD-ROM format in her printed book El libro del Fin del Mundo $(2002)^{* * *}$.

Fig. 1 - Screenshots of a) It's raining (1969) by Ana María Uribe; and b) Purpúreas Orquídeas (1996) by Belén Gache.
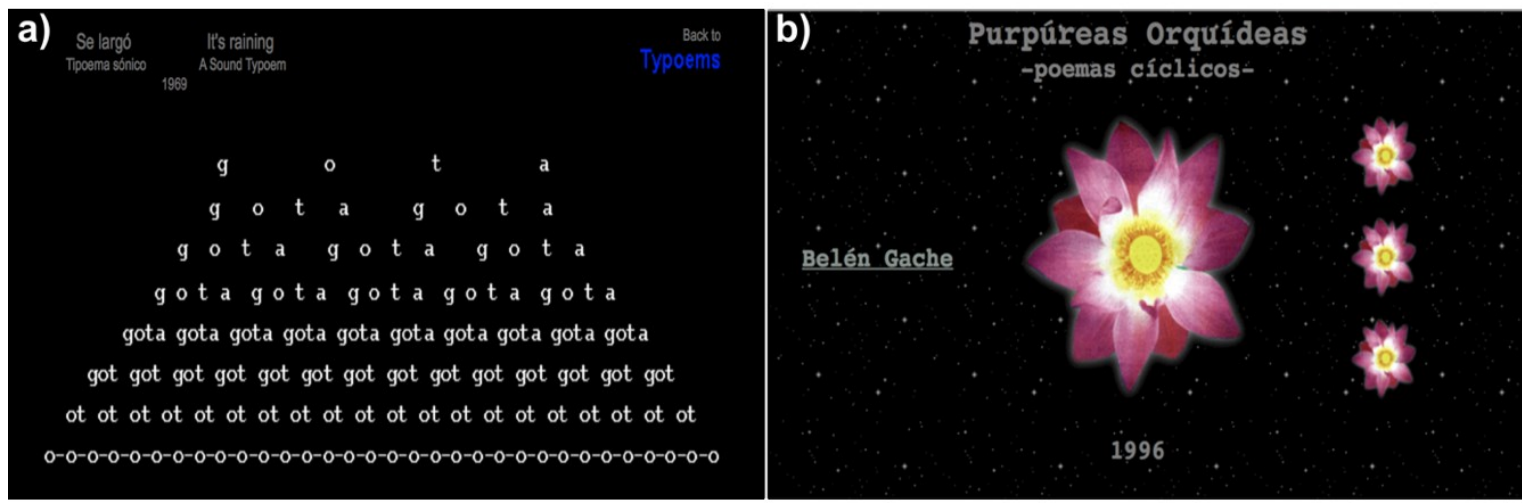

Experimentation with intertextuality and media can be seen in other early Latin American digital writers such as Mariela Yeregui (Argentina, 1966). Her interactive piece Ephitelia (1999) ${ }^{\dagger \dagger \dagger}$ (HTML, JavaScript, web-based) (Fig. 2a) consists of a collage map of the human body (brain, heart, mouth, eyes, genitals and feet) that the reader can explore through scanned photographs, sketches, drawings, handwritten notes and audios. Quotations making poetic allusions to specific body parts -by Julio Cortázar, James Joyce, Alejandra Pizarnik, Jacques Derrida, Sylvia Plath and James Carseappear randomly on the screen as pop-up window alerts. Visual dynamism and onscreen poetics are produced by the multiplication of media products and the emergence of multiple windows that at times make the interactor lose control over the interface. From a different perspective, this is an example of a visually "busy" and "typographically" dense aesthetic referred by María Enberg (2010) as an "aesthetic of visual noise". The experimentation between intertextuality, crowded screens, programming languages like HTML and JavaScript, and the use of English as a foreign language to explore "how body distances were culturally different from cultural distances, $\$$ as well as to portray

\footnotetext{
*** In terms of her contribution to e-lit per se, we also find the hypermedia works Wordtoys (2006) and Góngora Wordtoys (Soledades) (2011).

${ }^{\dagger \dagger}$ The work was created at the hypermedia lab in UCLA (USA) during a visiting scholar stay.

$\mathrm{H}$ "At the time I was living in Los Angeles and I was interested in how body distances were culturally different from my cultural distances. So, I thought about making this virtual body that enabled the 'touch' (of the mouse) in which many could touch a body and deconstruct it. Ephitelia is a body in friction".". Interview with the artist by email (March $\left.6^{\text {th }}, 2020\right)$
} 
these thoughts as "a body in friction" gives Ephitelia the poetic creativity emerging from migration experiences in Latin American electronic literature creations.

The digital works of multimedia visual artist and curator Gabriela Golder (Argentina, 1971) can be traced back to the mid 90's. Her early work Postales [Postcards] (19992000) (HTML, Dreamweaver, web-based) is an interactive multimedia narrative in Spanish and French defined by the author as "Una poética de lo extranjero. Viaje y palabras. Distancia y discursos." [“A poetics of the foreign. Travel and words. Distance and discourses"] (Golder, Presentation). Postales is composed of 220 screens/postcards about memory, identity and (linguistic) migration. In the same experimental vein as Yeregui, it is among the first Latin American electronic literature works to show the role of migration as poetic inspiration. ${ }^{\S \S}$ Golder connects this theme with her work through the aesthetics of the screen, where she explores the opacity and fragmentation of narrative alluding to the "code" hidden behind it, the unknown, the void, the unexpected, the traces. Golder ingeniously plays with the idea of programming language and unites it with migrating vocabulary: "re[start], re[store], algo[rhythm], exe.cutable, crash". The artist invites the reader to erase the scars of the past by leaving no traces in the present (i.e. screen) where pop-up windows (similar to Yeregui's Ephitelia) play an important role in fragmenting the narrative, "Yo cuento mi historia yo la desfiguro" [I tell my story I disfigure it] (Golder, Presentation).

Another figure with a long career in the fields of digital art and literature is Marina Zerbarini (Argentina, 1952). Zerbarini is a net art researcher, painter, photographer and creator of multiple art installations who has been exploring the relations between art and media since the early 90's. Azul intenso en un profundo mar [Deep blue in a deep sea] (2000) (Macromedia Flash, CD-ROM) (Fig. 2b) is considered her earliest digital literary work. It consists of a CD-ROM hypertextual narrative based on a romantic chat in real time using the social software ICQ. This work is also the precursor of her wellknown hypertext project, Eveline: fragmentos de una respuesta [Eveline: fragments of a reply] (2004), an intertextual approach that combines James Joyce's writing style, Argentina's recent political history and most importantly the idea of intertextuality between (her own) digital works. According to Claire Taylor (2019, p. 87), "Zerbarini envisages Joyce's short stories as springboards to examine the potentials of digital

$\S \S \S$ Golder created this piece while studying a master's degree in Hypermedia at the University of Paris. 
technologies (hypertext as a mechanism; the possibility of random association; the increased potential for user-reader participation; and the simulation of systems)". Moreover, Zerbarini's creative leitmotif: "the work stops being an object and is transformed in behaviour" (Zerbarini, Personal Website) can be experienced in other early pieces such as Shadows (2000) and The Dream is gone (2001), both interactive CD-ROMs that evoke sensuality, intimacy and opacity through simple interaction, audio files and the image of an unmade bed as a background. In 2014, together with Alejandro Schianchi, Ignacio Nieto, Diego Dalla Beneta, and Liliana Koselevich, Zerbarini co-wrote the book, Radiografia del Net.Art Latino. Vitalidad creativa en riego de extinción [Radiography of Latin American Net Art. Creative Vitality in Risk of Extinction], an important contribution to the study of Net.Art in Latin America.

Among the Latin American women creators who appeared in Radiography of Latin American Net Art. Creative Vitality in Risk of Extinction, we find Laura Benech (Argentina 1970), a contemporary artist and lecturer who has been working with new media since the 90's. In 1998, Benech created the interactive CD-ROM Anónimo [Anonymous]. The piece proposes a labyrinthine journey between public and private urban imagery using photos, sounds, videos, maps and data from a phone book to create a nonlinear narrative. In a recent interview, she raised two important points: a) the current issues around the security and privacy of our data and b) the rapid obsolescence of digital works, "I say this aware of the incredible moment we are experiencing today, moment from which perhaps the word 'private' becomes obsolete just like the technology (Macromedia Director) with which I carried out that project".**** Benech was among the artists that during the interviews underlined the problematic of obsolesce and preservation strategies in digital literature when referring to her early pieces. Lastly, it is important to mention that from 1998 to 2008, together with Lila Pagola (Argentina, 1972), she co-organised the "Jornadas de arte y medios digitales" ["Art and Digital Media Days"] in the Argentinian city of Córdoba, one of the most pioneering events to discuss the production and dissemination of Latin American internet works.

${ }^{* * * *}$ Interview with the artist by email (March $\left.28^{\text {th }}, 2020\right)$. 
Fig. 2 - Screenshots of a) Ephitelia (1999) by Mariela Yeregui; and b) Azul intenso en un profundo mar (2000) by Mariana Zerbarini.

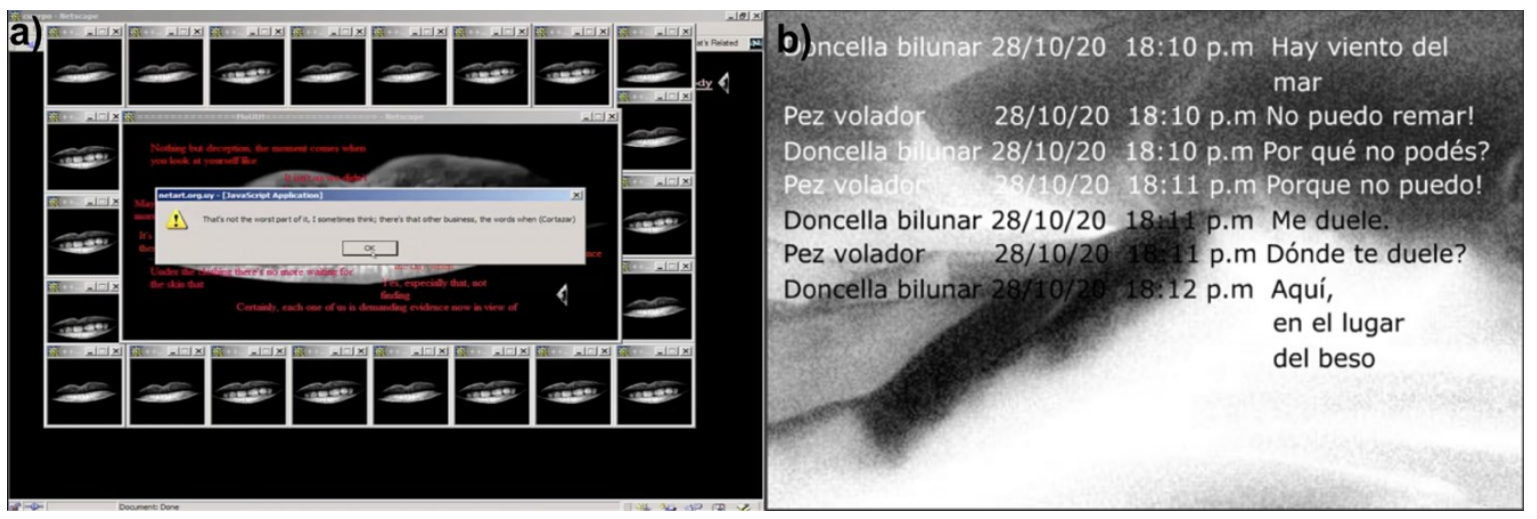

\subsection{Chile's early multimedia literary and art projects}

On the Chilean literary scene, a poet, artist, filmmaker and activist who began creating art installations since the 60's is Cecilia Vicuña (Chile, 1948). She refers to the works that she created in this period as "Arte Precario" [Precarious Art], "my early works were not documented, they existed only for the memories of a few citizens" (Vicuña, Personal Website). The work "quipu that remembers nothing" (1966) (an empty cord) was her first piece of "precarious art", along with her multiple projects called basuritas [little bits of garbage] (1966). In the 1980's she directed her first two films, What is poetry to you? (1980) (Film), an art documentary revising and expanding the definition of poetry by interviewing people in the city of Bogotá, Colombia; and Paracas (1983) a three-dimensional animation of a 2000 year old pre-Columbian textile created in the region of Paracas-Nazca Perú. Vicuña is one of the pioneer artists in Latin America to explore the relationships between weaving, language and nature.

Another long-standing Chilean researcher and writer is Diamela Eltit (Chile, 1949) who wrote the political and multimedial novel Lumpérica [E. Luminata] (1983) (Print and mixed media). This narrative project was written after the Chilean military coup of September 1973. It incorporates new narrative strategies and forms such as theatre, performance, photography and video installation (specifically her own video Maipú) into a print novel. According to Neustadt, Lumpérica can be read as a novel of resistance, a fragmentary narrative that suggests "a transtextual and multimedia continuum that spirals between fictional, corporeal, and visual performances" (1999, p. 24). Both Eltit and Vicuña's approach to mixing and remixing media in the early 1980's 
reaffirms that literary and artistic experimentation in Latin America was present since the very early days.

Eugenia Prado (Chile, 1962) is perhaps Chile's greatest digital literature female creator. In a recent interview, she acknowledged her first printed novel, "El cofre" [The chest] (1987-2013) as the beginnings of her literary experimentation with digital formats. However, Prado is best known for her installation novel Hembros: asedios a lo post humano [Fe/males: Sieges of the Posthuman] (2004-) (Installation) (Fig. 3a). A project in which she has been working for more than 15 years. The distinctive nature of Padro's work is the constant transformation, mutation and trespassing of literary and artistic boundaries at all times. In the interview, she described her creative process as follows, "I'm interested in risk. My right to decide. My right to fail. I am passionate about terror; the dark, the dense, the weird. I am interested in the fusion of elements, anti-psychiatry and psychiatry. The monstrous. Multimedia. The dissident writings. The monsters". ${ }^{\dagger \dagger \dagger \dagger}$ Fe/males is the perfect example of a transmedia project where constant transformation across multiple platforms and delivery channels takes place ${ }^{+1+t}$.

A few years later, multimedia artist and writer Andrea Wolf (Chile, 1979) created

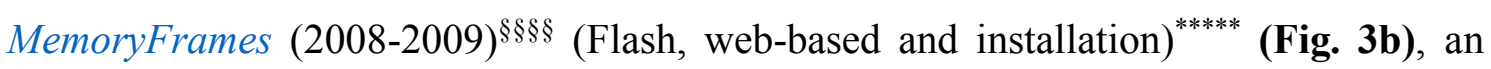
interactive narrative and video installation that presents memory as reconstruction and deconstruction. The idea behind the project is to create an experience that constitutes a visual archive of intimate and recent memories shaped by recurrent images appearing in Wolf's home videos. This allows the interactor to mix and link the characters' memories through images in order to create multiple narratives. According to Wolf, memoryFrames was a way to explore these ideas: "memory as a narrative construction and an action that is constantly updated, the notion that images become our memory; the archive as a producer of new information; and the thought or question

\footnotetext{
$+1+$ Interview with the artist by email, (April $21^{\text {st }}, 2020$ ).

+4 Cf. "Deambulo por las redes porque escribir es político y para mí lo micro funciona” Interview with Eugenia Padro by Carolina Gainza (2016).

$\S \S \S \S$ Wolf co-created this work with Silvia Laura Carli as part of her master's thesis at Pompeu Fabra University, Barcelona under the guidance of Eugenio Tisselli.

${ }_{* * * * *}$ The interactive installation was presented for the first time at the "Tesla: Digital Culture Meeting, Fundación Telefónica Art Room” in Santiago, Chile in December 2008.
} 
about whether our memories (or its images) are interchangeable". installations are a genre that will later developed specially in the Brazilian scene.

One other creator who deserves a mention in a loosely Chilean context is María Mencía (Venezuela, 1960). Born in Venezuela, Mencía was brought up in Spain and now lives and works in the UK. ${ }^{+1+\$}$ Mencía has been exhibiting her work in Latin America since 2002 and, in the context of the celebration of the first E-Poetry Festival to be held in Latin America (Buenos Aires, 2015), she turned to her Latin American roots for inspiration. El poema que cruzó el Atlántico [The Poem that Crossed the Atlantic] (2016-) (HTML5, CSS, JavaScript, web-based) is a response to her family's history of exile in Chile as a result of the Spanish Civil War (1937-39). She created a website documenting the context for the voyage of the Winnipeg, a user-generated archive for others involved to add their own memories resulting in a trilingual "poem" (English, Spanish, French) that offers the viewer/reader a way to access those archived memories in an aleatory manner by clicking on random letters that seem to float against a murky grey-blue "sea". Currently, Mencía is developing a new interactive multimedia narrative, Mujeres voces invisibles (2020), ${ }^{\S \S \S \S}$ a work that addresses the possibility of representing women's silenced voices in the context of the post-conflict era in Colombia.

Fig. 3 - Screenshots of a) Hembros (2004) by Eugenia Prado and b) memoryFrames (2008-2009) by Andrea Wolf.
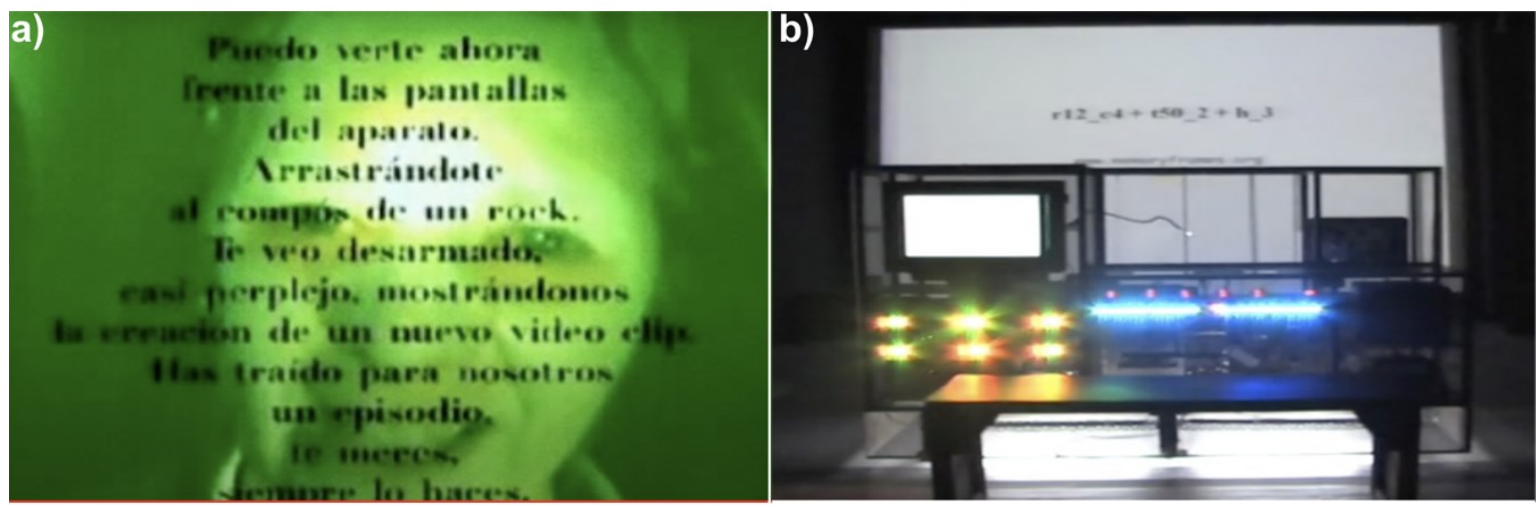

$+1+\dagger$ Interview with the artist by email (March $31^{\text {st }}, 2020$ ).

H+A Among Mencía's earliest works in the UK, we find installations, video-poems and performances such as 7 minutes of passion (1992) and Tell me that you love me (1993). The latter is a fax machine connected to a remote-controlled car that goes over the words "I love you" to produce aleatory phrases and drawings on a different surface; this experimental installation is considered her first electronic literature creation.

$\S \S \S \S \S$ This work is part of larger AHRC project "Memory, Victims, and Representation of the Colombian Conflict" led by Professor Claire Taylor at the University of Liverpool, UK. 


\subsection{Brazil's hypertextual essays, interactive narratives and digital art exhibitions}

Brazil has also a long tradition in the fields of electronic literature and art ${ }^{* * * * *}$. In 1999 Giselle Beiguelman (Brazil, 1962) created the hypertextual and visual essay, The Book after the Book (HTML, JavaScript, web-based). She has described it as "non-linear narratives, which reconfigure the literature/book relationship starting from the very notion of volume" (Beiguelman, Personal Website). Performativity and resistance are key elements to the piece. An electronic literary work that questions the future of the printed book by using linguistic text, animation, images, and videos. Other works include Leste o Leste? [Did You Read the East?] (2002), Poétrica (2003), //**Code_UP [2004]), The QR Poem [2010]) and recently the hypertextual essay, Coronário [Coronary] (2020) in response to the COVID-19 pandemic. Similar to Yeregui's visual dynamism and fragmentation in Ephitelia (1999), Beiguelman's work evidences an extensive experimentation with the movement back and forth - hence "nomadic"between different platforms/screens and between different languages - phonic, human languages, non-phonic scripts and programming languages.

Regina Célia Pinto (Brazil, 1949) is a researcher and visual artist. As a visual artist, she has participated in many exhibitions both as an exhibitor and a curator. Her interest in net art and cyberart started in 1999 when she created O Branco e o Negro, Reflexões sobre a Neblina [The White and the Black, Reflections on the Fog] (Macromedia Flash, CD-ROM), a piece inspired in The Rouge et Le Noir (1830), Stendhal's novel, and the Brazilian poem "Fog" (1996) by Nelson Ascher. In 2002, she created Museu do essencial e do alem disso [The Museum of the Essential and Beyond That] (2002). This is an archive of digital works by not only Latin American but also international artists showing the evolution of technological discourses and practices. In an interview, the artist described it as follows, "The project consists of creating virtual architectures: a museum with its libraries and galleries, which have no real-world counterparts [...] A museum that does not exist and whose architecture and works are made up of numbers 01010101." "itit广 The Museum of the Essential and Beyond That stands among the first examples of preservation, archiving and dissemination of digital literature and art by a Latin American artist. Additionally, Pinto is the creator of the Flash piece Viewing

\footnotetext{
****** I would like to mention here the Brazilian digital journal "Artéria 8" (2003-2004) edited by Omar Khouri Fábio Oliveira Nunes where multiple works of Brazilian Digital literature can be found. $++1+1 \dagger$ Interview with the artist by email (February $\left.23^{\text {rd }}, 2020\right)$.
} 
Axolotls (2004) that uses and adapts Julio Cortazar's story "Axolotls" (1964). Lastly, she translated into Portuguese Jim Andrews's poem Seattle Drift (1997) in 2006, and thus most probably became the first woman translator of electronic literature in Latin America.

In the field of generative systems of art, we find Vera Sylvia Biguetti (Brazil, 1956), a sculptor, painter and multimedia essayist. Her earliest play/paint works using art generator software include Stereoscopy Space (2003) (Fig. 3a) and Gr@fite (2004) (Director/Shockwave, web-based and CD-ROM). These pieces are a splash of generative art and colour that "show reactive, generative and interactive software applications as an amusement" where depending on the object and the interaction "the spectator is changed into a graffiti creator or a DJ" (Biguetti, Personal Website). The installation requires a computer, a projector multimedia, two loudspeakers, 3D glasses and a wireless mouse. Another work, echoing Beiguelman's hypertextual and visual essay The Book after the Book (1999), is Objeto Livro Jogo [Object, book, game] (2004) a playful combinatory narrative that offers a continuum of different interpretations and meanings around the subject of the book both as hybrid and as virtual object.

Another interdisciplinary artist and researcher who has been leading art and technology projects since 1989 is Lúcia Leão (Brazil, 1963). Among her first interactive works we find, Qual é o seu sonho? (2002) [What is your dream?] (HTML, JavaScript, webbased), Plural maps; lost in São Paulo (2002) (VRML, Installation) (presented for the first time at the XXV São Paulo Art Biennial), and Hermenetka (2005) (HTML, Javascript, web-based). Leão explores digital urbanism and Brazilian cyberculture using VRML labyrinths generated out of maps, images, texts, videos and/or hyperlinks of different Brazilian cities. Her interest in the relation between literature, labyrinths, rhizomes and hypertexts has been studied in her books Labirintos do Pensamento Contemporâneo [Labyrinths of Contemporary Thought] (2000) and A estética do Labirinto [Aesthetics of the Labyrinth] (2002).

As above-mentioned, the role of exhibitions is key in the chronological history of electronic literature in Latin America and for this Brazil has set an example in the region for years (e.g. São Paulo Art Biennial, 1951). Exhibitions have been a place to 
display new media art and cultural production more generally, as well as to exchange ideas and criticism with other contemporary artists at a regional and international level. For instance, "POIESIS. BETWEEN_PIXEL_AND_PROGRAM" was presented at the Oi Futuro Art Centre in Rio de Janeiro from October $23^{\text {rd }}$ to Dec $3^{\text {rd }} 2007 .+4+\$$ Among the featured artists there were two Brazilian women, Adriana Calcanhotto (Brazil, 1965) and Lenora de Barros (Brazil, 1953).

Calcanhotto is a writer, composer and singer. In 2003, she published her first poetry book Algumas Letras [Some Words], a collection of poems, and in 2006 she performed for the first time her visual poem "Between the Word and the Image". Her sound installation Over and Over, Even (2007) was part of the POIESIS exhibition. Among her latest work, we find the digital poem Augusto (2011) (Flash, web-based), a homage to Augusto de Campos on his $80^{\text {th }}$ birthday. De Barros is a poet, performer and a video artist. She created one of her first visual poems, Poema in 1979, a series of photographs depicting the artist's tongue interacting with the mechanism of a typewriter (Fig. 3b). She spent much of the 1980s writing visual poems and in 1983 she published her first book, Onde se vê [Where it's seen]. Her poetry was greatly influenced by the Noigandres group, formed by Augusto de Campos (1931-), Haroldo de Campos (19292003) and Décio Pignatari (1927-2012). That same year De Barros presented her visual and photo-performatic poetry at the XXVII São Paulo Art Biennial in a section titled "Arte e videotexto" [Art and videotext] (1983). Her works See me (2003) (Flash, web-

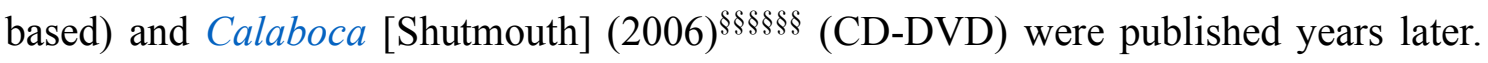
The latter was part of the POIESIS exhibition. It was a video performance showing a hammer driving nails into a human mouth to write the word: S I L E N C E.

\#+tt The exhibition was cured by André Vallias, Friedrich W. Block, Adolfo Montejo Navas. Artists included: Adriana Calcanhotto, Arnaldo Antunes, Augusto de Campos, Aya Karpinska, Betty Leirner \& Florian Kutzli, Eduardo Scala, Florian Cramer, Joao Bandeira, JODI, Jörg Piringer, Johannes Auer, Lenora de Barros, León Ferrari \& Ricardo Pons, Luis Andrade, Marcelo Tápia, Omar Khouri, Ricardo Aleixo, Ronaldo Kiel \& Anita Cheng, Simon Biggs, Uli Winters, Walter Silveira, Wlademir Dias Pino, Young-Hae-Chang-Heavy-Industries, Zebra Poetry Film Festival.

$\S \S \S \S \S \S$ Edited by Lenora de Barros and Luciano Mariussi; Camera and photograph: Luciano Mariussi, Sound: Cid Campos. 
Fig. 4 - Screenshots of a) Stereoscopy Space (2003) by Vera Biguetti; and b) Poema (1979) by Lenora De Barros.

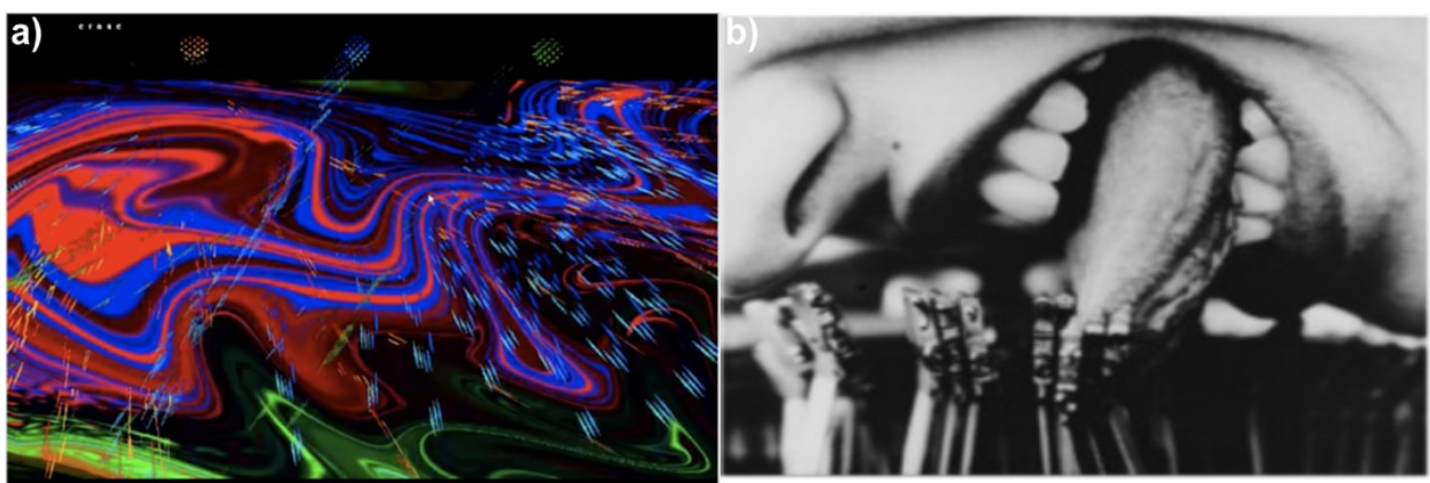

\subsection{Bolivia and Peru's early interactive narratives and video installations}

Some of the very earliest works, though notably quite technically-advanced for their moment of composition, is the autobiographical project Sangre Boliviana [Bolivian Blood] (1994) (MicroMind Director, CD-ROM) by artist Lucía Grossberger Morales (Bolivia, 1952), an interactive multimedia piece containing 9 stories based on the author's personal relationship with Bolivia. This piece includes two of Grossberger's first creations: A mi abuelita (1992) [To my grandmother] a piece inspired by the "Day of the Dead" that consisted of a monitor that showed the face of the spectator followed by a skull that emerged and began to laugh; and Cholera (1992) [Cholera], a video game inspired by people who died of cholera in Cochabamba during a visit by the artist in the 90s. Grossberger's work explores the feeling of belonging to two or more cultures and finding a way to express it. The impact on women in particular of issues such as migration and biculturalism are elements that emerge in these two works in the mid 90's, and that are certainly also in evidence in other Latin American digital works such as Golber's Postales, (1999) and Yeregui's Ephitelia (1999) $)^{* * * * * * *}$.

Angie Bonino (Peru, 1974) is a Peruvian multidisciplinary artist and curator who has been interested in the interconnections between new media and art since the early 90's. Her artistic work includes video, performance, installation, painting, photography, poetry, narrative, sound design, and drawing. Among her earliest works we find,

In the same experimental vein, Chicana artist Jacalyn López García (USA, 1960) created Glasshouses: A Tour of American Assimilation from a Mexican-American Perspective (1995-1997) (HTML, web-based), a multi-layered interactive website containing 32 linked-screens reflecting on the Chicana suburban life experience in the USA. 
Schemes (1995) (Media 100, Video Installation), Retrospective of Toxic Plastic Stuff (1998) (Video Installation) and Mr. President (1999) (Video Animation). The latter was made in the period of Alberto Fujimori's dictatorship in Peru, as described by the author, it was "a risky project at the time, due to the satirical content. But it managed to show itself across the country at a time when such art works were repressed and censored" (Bonino, Vimeo). Bonino has made a book of conservation of digital files and electronic media edited by the Government of Bogotá Colombia and ART NEXUS 2012 Foundation. Additionally, she is the director of the video art festival, "VideoAKT International Festival". Though I am aware the documentation of Bolivia and Peru is limited, it is a first step and an invitation towards studying the emergence of digital practices in these countries.

\subsection{Mexico's first virtual reality environments and current creative laboratories}

According to Claudia Kozak, Latin American electronic literature depicts "literary creation in contexts of experimental communities, creative laboratories and disruptive social technologies" (2018, p. 10). Our current survey shows that when creating e-lit in Latin America many artists work in collaborative and collective settings. For instance, directed by video-artist Grace Quintanilla (Mexico, 1967-2019), the Centro de Cultura Digital (2012) in Mexico City is a key centre for the creation and dissemination of digital literature and culture in Mexico and Latin America more widely. Mónica Nepote (Mexico, 1970), a sound/performance poet, is the current director of the Centre's "Eliterature" project where she has driven and coordinated an important collection of e-lit works. The concept and practice of collaboration and collectivity among women has played an important role in this project where women creators have been involved in the development of more than 60 percent of the pieces. Such e-lit works include, Yolanda de la Torre (Mexico, 1967), Raquel Gómez (Mexico, 1986) and Nadia Baram's (Mexico, 1981) Umbrales [Thresholds] (2014) (HTML, JavaScript, CSS, web-based), an interactive hypertextual work composed of multiple texts -written by patients at a psychiatric clinic- that explore the thresholds, similarities and associations between the complexities of the mind and the interface; and Xitlálitl Rodríguez (Mexico, 1982), Julie Boschat (France, 1988) and Raquel Gómez's Catnip (2015) (HTML, JavaScript, CSS, web-based), a collaborative and playful piece that serves as a metaphor between feline creativity and aesthetics, and programming languages and poetry. 
Additionally, the Antología de Poesía Electrónica [Anthology of Electronic Poetry] (CCD) was launched in 2018, including Romina Cazón's (Argentina, 1982) La poesía es una diosa [Poetry is a Goddess], (HTML, JavaScript, CSS, web-based), a set of animated poetry statements that question the power of poetics over politics and vice versa; Nadia Cortés' (Mexico, 1985), Filiaciones textuales [Textual Afiliations] (HTML, JavaScript, CSS, web-based), an interactive piece that plays with the grammatical structure of the main story to create multiple narratives by using word trees and constellations; Ana Medina's (Mexico, 1988) Seis minutos para tomar el T [Six Minutes to take the T](HTML, JavaScript, CSS, web-based), a great example of "stream of consciousness" that depicts a urban mindscape scenario where the flow of thoughts and emotions mirrors the velocity of our minds' visual memory; and lastly Carolina Villanueva's (Mexico, 1989) De ti a mi no hay distancia [From you to me there is no distance] (HTML, web-based), a writing/painting digital calligraphy interface that allows collaborative creation between the author and her readers.

Furthermore, two pioneering Mexican creators who deserve a particular mention are Grace Quintanilla (Mexico, 1967-2019) and Tania Aedo (Mexico, 1968). Quintanilla started creating video art in the mid 90's. Among her first works, we find, Mambo

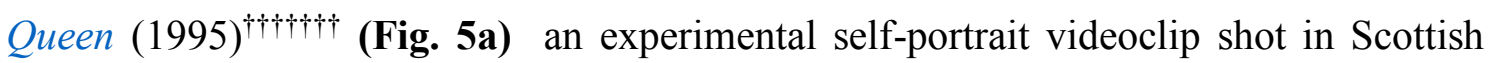
landscapes that explores the interrelations between femininity and nature, echoing Uribe's and Gache's approaches on this same theme; Viceversa (1998) (Macromedia Flash, CD-ROM) an interactive narrative inspired in the life of two elderly artists that parallels the reconstruction of their story with the "deconstruction" of their physical appearance; and Bits de memoria (1999), the remediation of a personal memory (a family's pencil sketch photograph) into an interactive installation. Aedo's Y/O (1995) (Unix, VR) (Fig. 5b) is a virtual reality environment developed in Unix by using a Silicon Graphics computer. The idea was to create "avatars" that were armed with body parts bearing gender stereotypes of beauty and colour that the public could mix to create a virtual body (avatar). The work was inspired by the first internet chat systems (IRC) and the first graphic chats (The Palace). Y/O was exhibited for the first time in 1997 in Mexico City's Multimedia Centre. During an artistic residence at the Banff Centre for Arts and Creativity (Canada), Aedo developed a second project Bodies in Progress

$+1+1+\dagger$ This work was created while Quintanilla studied at Duncan of Jordanstone College of Art, University of Dundee, Scotland. 
(1997) (VR, web-based), a 3D multiuser virtual reality environment where, in the same experimental vein as $Y / O$, users communicated via text chats and created avatars with different identities and characteristics.

In recent years, Laura Balboa (Mexico, 1979), Karen Villeda (Mexico 1985) and Minerva Reynosa (Mexico, 1979) have also developed works of electronic literature. Balboa's playful collection of "code poetry", you CODE me (2009) (Print-digital), also written "you \&\#67; \&\#79; \&\#68; \&\#69; me", is available online as a PDF to print out or, in a different variant, as a Flash book. Similar to Beiguelman's work, it attempts to reinscribe human communication and interactions in the semantics of code by writing non-executable HTML code that humans therefore have to decode for themselves. Although Villeda's first work is $\mathrm{LABO} /$ laboratorio de ciberpoesía [LABO/ciberpoetry laboratory] (2010) (HTML Action Script, web-based), she is best known for the project POETuitéame [POETweet Me] (2014) (Twitter, web-based), co-created with Denise Audirac (Mexico, 1988), which offers the reader the chance to participate in a generative poetry experiment based on recent activity on Twitter. Villeda has also created other works of hypermedia poetry in a similar vein to Gache, Yeregui and Zerbarini's intertextual works: see, for example, Sorjuanizate [Sorjuanise Yourself] (2016) (HTML, CSS, web-based) inspired in Mexican poet Sor Juana Inés de la Cruz's "Primer sueño" (1692). For her part, Reynosa has worked together with e-poet partner Benjamín Moreno to produce Mammut [Mammouth] (2015) (App iOS), a collection of "concretoons" - a neologism bringing together concrete poetry and cartoons, where the poem is delivered as part of a retro-style video game.

Fig. 5 - Screenshots of a) Mambo Queen (1995) by Grace Quintanilla); and b) Y/O (1995) by Tania Aedo.

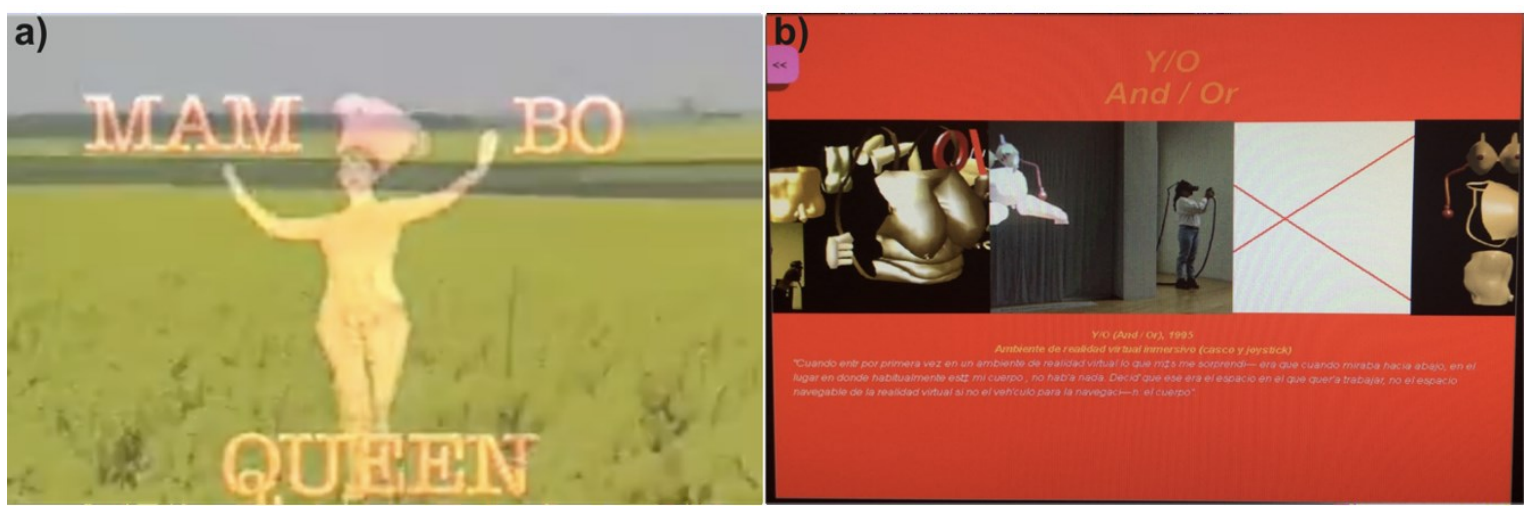




\subsection{Are Blogs e-lit? Blogging in Cuba, Chile and Costa Rica}

As we have seen, many works of electronic literature by Latin American women have been avowedly collaborative projects. In much recent work this undoubtedly has to do with the increasing technical complexity of the projects and the limitations of any one individual's skillset, but also, in the case of many of the works reviewed here, group work, collaboration with specific existing communities, and/or the creation of new affective communities around a work, is very much part of the point. The desire to create communities (writing networks) is also a defining feature of many blogs written by women. While blogging is not typically included in definitions of e-literature, it is here that Latin American women writers can be seen to have their biggest impact in terms of garnering, and occasionally mobilising, an audience. The tendency is to accept "blog-novels" such as Hembros: asedios de lo post humano (2006-) (Blogger, webbased) by Eugenia Prado Bassi (Chile, 1962), but not non-fiction blogs. The reticence to accept non-fiction blogs as e-literature may be because they are seen as being too easily "printed out" so not "electronic" enough (although this is disputable these days), or because they are not "literary" enough (though blogging fits very well with that sui generis Latin American literary genre, the chronicle).

Blogging has really flourished in Cuba, despite restrictions on internet access. At the peak of its success in 2008-09, and after being blocked by Cuban government censors, the blog Generación Y (2007-) (Bitban, web-based), ${ }^{+1+1+1}$ written by Yoani Sánchez (Cuba, 1975), was receiving an average of 10 million visits and 30,000 comments a month), and was being crowd-translated into multiple other languages (HENKEN, 2010). While some of Sánchez's work has a feminist focus, her main aim is to vent her frustration with the state of contemporary politics in Cuba, and propose a "revolution" of her own, powered by digital technologies. In contrast, in Negra cubana tenía que ser [It Had to Be a Black Cuban Woman] (2006-) (WordPress, web-based), by Sandra Álvarez Ramírez (Cuba, 1973), the author takes a less Manichean approach to politics in Cuba and focuses instead on the intersectionality of the Black, female, queer experience. As stated by Sierra Rivera (2018), Negra cubana is most "revolutionary" for its attempt to network “a cyberfeminist agenda to connect Cuban black women's

+t+tt The blog was originally hosted on Desde Cuba, moving to 14ymedio in 2014. 
voices with other voices around the world" and "create safe online networks where women can openly discuss any issue without being threatened".

In Costa Rica, writer Dorelia Barahona created the blog Milagros sueltos: novela colectiva [Sundry Miracles: Collective Novel] (2007-2008) (WordPress, web-based). Barahoma invited five Costa Rican and one Spanish writers (Floria Bertsch, Janina Bonilla, Víctor Valdelomar, Catalina Murillo, Jaime Ordóñez, Pedro Pablo Viñuales) to join her project, "Blogs were a little used at that time in Costa Rica and I found it very innovative to use the internet so that more people could read the novel. The blog novel was also published in print format" only collective novel writing project where seven different characters (Paola, Amelia, Ana María, Renato, Greivin, Rosario, Dario) interweave stories relating to a particular day, 1 August, the day of Our Lady of the Angels, patron of Costa Rica and the annual Pilgrim's walk to the city of Cartago.

\subsection{The emergence of the Colombian and Southern Cone e-lit scene}

Latin American e-lit programmers and designers have been present in the Electronic Literature Collections since 2006, -Giselle Beiguelman and Helga Stein created "Code Movie 1" in 2004. Another example is Cynthia Lawson Jaramillo (Colombia, 1975), a Colombian programmer and designer, who collaborated with Stephanie Strickland and Paul Ryan in the creation of two e-lit works that appear in the ELC2 (2011): $V$ : Vniverse (2002) and Slippingglimpse (2007). Among Lawson Jaramillo's individual early works, we find 28 days (2007) (iSight camera, web-based), a video-a-day project that consisted in her recording her daily activities in front of her computer in order to analyse her gestures and performances; Pompidou from Above (2008) (Flash, webbased) the exploration of the poetry of movement, capturing nature and human silhouettes of "hidden choreographies" in urban and semi-urban spaces (e.g. Paris and Rio de Janeiro); and Voicemail Diaries (2009) (Mobile, web-based), a recording of voicemails on her phone presented as an archive for voice memories.

Another Colombian artist and researcher is Carmen Gil Vrolijk (Colombia, 1974) who created Zirma an audio-visual poem in Flash inspired by Italo Calvino's Invisible Cities

$\S \S \S \S \S \S$ Interview with the writer by email (May $12^{\text {th }}, 2020$ ) 
in the early 90's. In a recent interview, she mentioned that due to the obsolescence of many computational programs such as Flash Zirma is lost and no longer available, "Unfortunately, Zirma is a work made in an old version of Flash, it does not work online anymore, and I cannot access the original files" ${ }^{, * * * * * * *}$. Years later during an artistic residence in Mexico, together with Cuban artist Camilo Giraldo Ángel, Gil Vrolijk co-created the hyperfiction El alebrije $e^{\dagger+\dagger \dagger \dagger \dagger}$ (2004) (Macromedia Flash, Dreamweaver, web-based), a more complex hypermedia collection of "crónicas de viaje, diarios y seres del caos" [travel accounts, diary entries and chaotic beings] structured around a young photographer's discovery of a travel diary that leads her to an exploration of the more "fantastic" side of contemporary Mexico. Another example of hypertext fiction is Mónica Montes Ferrando's (Colombia, 1973) Desde aquí [From Here] (2001) (Macromedia Flash, Dreamweaver, web-based), a hypertextual work telling the interrelated stories of Sofía, Mara and Carlos, set in an imaginary city that stands as a symbolic-labyrinthic space to awaken the characters' memories. The letters in the work's title act as doors to begin the story [D] [E] [S] [D] [E] [A] [Q] [U] [I], each letter triggering a personal memory about migration told from a unknown location (From Here), the watercolours that accompany the work were painted by Montes as a way to mix painting and literature.

Recently, writer and visual artist Carolina López Jiménez (Colombia, 1980) created the interactive multimedia narrative, Retratos vivos de mamá [Living portraits of my mother] (2015-) (HTML5, CMS, CCS3), a personal project triggered by the death of her mother that explores the possibility of healing grief through creation. By gathering voice recordings, drawings, photographs, letters, and official documents from different sources, López-Jiménez reconstructs her mother's life and memories thanks to the collective memory of family and friends. Retratos vivos de mamá combines different genres such as video art, documentary, and hyperfiction into a digital work. The idea of mixing different genres in contemporary literary creations can also be found in the hypermedia narrative Mandala (2017) (HTML5, JavaScript, CSS, web-based-print) (Fig. 6a). Written and developed by long time writer and researcher Alejandra Jaramillo Morales (Colombia, 1971), this eight-year-long project blends multiple literary genres

\footnotetext{
******** Interview with the artist by email (March $\left.3^{\text {rd }}, 2020\right)$. $+1+1+1+\dagger$ 'Alebrijes' are Mexican handicrafts consisting of colourful papier-mâché models of imaginary creatures.
} 
(poems, interviews, diaries, essays, short-stories), in a non-linear and fragmentary narration, ingeniously constructed around the image of an interactive "mandala", $++1++$ " to tell the story of Amaura's life and memories in Bogotá. The work is also a printed book and was originally developed in Flash and then migrated to HTML5 for its final

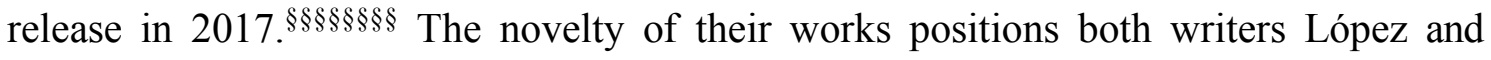
Jaramillo as are examples of the emergence of literary experimentation on the Colombian e-lit scene.

In Argentina, Paraguay and Uruguay, the Itaú Foundation has an annual digital short story contest that has been running since 2011 , its aim is to promote short story writing through digital resources in the Southern Cone nations of Latin America. Even though not all the stories are digital-born, experimentation with new platforms and media is present in the selected works. For instance, the Itaú Anthology of Digital Stories 2018: "De papeles y pantallas" [Of paper and screens] comprises 18 works out of which 5 are considered digital stories, and out of those 5 only 2 are written by women. Loren Pose Rivero (Uruguay, 1983) is one of these writers. Her creation Cae [Fall] (2018) (HTML5) is a hypertextual narrative about nature, mythology and fate. The idea behind the work is to create a reading experience of "narrative vertigo" by clicking on the hyperlinks "cae" [fall] and "salta" [jump]. This effect creates the feeling of falling off a cliff or jumping into the sea every time the reader clicks to advance in the story. In her second interactive narrative, Palabroscopio (2019) (HTML5) (Fig. 6b) which is included in the recently published Itaú Anthology of Digital Stories 2019: "Caminos narrativos" [Narrative Paths], ${ }^{* * * * * * * * *}$ Pose-Rivero explores the hidden voices of an abandoned coffee house that is inhabited by mobile phones, living portraits, vampires and fortune-telling crystal glasses. Colour and fiction play an important role in the work as the colour of the character's eyes dictates the story's genre: blue is for science fiction, pink for romance and red for horror. Pose-Rivero's digital works are an example of the rise of Southern Cone women artists in the Latin American e-lit scene.

$+4+1+4$ A 'mandala' is a symbolic representation of the universe. It is used in sacred rituals and as an aid for meditation in Buddhism and Hinduism.

$\S \S \S \S \S \S \S$ “The novel had several steps before being published and purchased online [...] a first version was made in Flash that was quite obsolete, and it could not be published, but it served to show to the editors". Interview with the artist by email (March $\left.10^{\text {th }}, 2020\right)$.

********* "Caminos Narrativos" [Narrative Paths] comprises 22 works out of which 3 are considered digital stories, and out of those 3 only 1 is written by women (Loren Pose). 
Fig. 6 - Screenshots of a) Mandala (2017) by Alejandra Jaramillo and b) Palabroscopio (2019) by Loren Pose
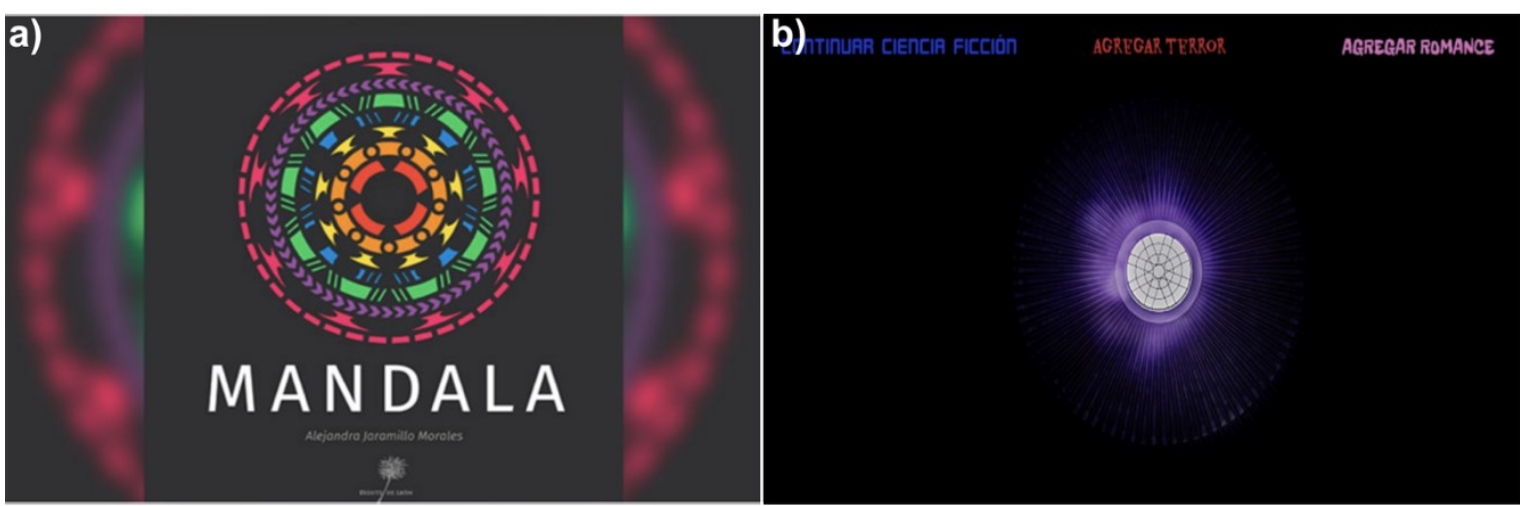

\section{New voices and directions: scientific poetics}

At the beginning of this overview I noted that there are female writers/artists/programmers who have not (yet) been included in the collections and databases mentioned. In this regard, there are several women artists working at the intersection of art, science and technology in Latin America that I have decided to include in this chronological review. According to Scott Weintraub (2018, p. 1), "In Latin American techno-poetry there are numerous sophisticated examples of works whose scientific poetics make a strong case for a growing transdiscursive space in which to situate new media production by Latin American authors". From our perspective, such scientific poetics could be exemplified in the interdisciplinary art projects of Yto Aranda (Chile, 1966), Amor Muñoz (Mexico, 1979) and Sandra De Berduccy (Bolivia, 1976), to name but a few.

Aranda is a visual poet and digital artist who has been working on art and technology since the early 90's. In her works, she merges painting with new electronic and digital tools to create a set of interactive e-paintings [pintura electrónica interactiva]. For instance, e-pintura DEMENCIAL (2009-2010) is a mix of electronic circuits and acrylic paint that generates a "dynamic pictorial language" that simulates the interactor's contact with nature by manipulating colour, light and sound (Fig. 7a); $(((K O))) \varepsilon>$ $<\left(\left(a Q u a \_\right.\right.$esfera $\left.)\right)>-<3$ (2017) is an electronic, acoustic and visual mural consisting of 8 hexagons (read as communities) that represent the water cycles. The piece's soundscape includes the sea, the rain and the rivers. The project's name $K O$ means 
water in mapudungún [Mapuche language] and aQua_esfera refers to our planet's hydrosphere.

Muñoz is a visual and multimedia artist who has been exploring the relationship between technology and society since 2007. Among her experimental electronic installations we find, Poem Meteor (2015), an interactive piece that generates and engraves poems about light, rainbows, stars and planets on 3D metallic-like meteorites. In the artist's words, the project "seeks to create a connection between theory and poetics, to see science as a search for beauty and art as the creation of organized processes and systems" (Muñoz, Personal Website). A different piece, Data Digital Code Red (2019), is a series of interactive handwoven textiles with hidden coded messages between their patterns that the interactor has to decipher by using a binary alphabet created by the author. Muñoz's work seeks to problematize the figures of the artisan and the programmer by generating technological pieces using traditional crafts -such as these handwoven textiles- in search of common narrative structures between them.

De Berduccy is new media artist, weaver and specialist in Andean textile techniques. Texto Textil Código [Text Textile Code] (2011) is a series of research-based installations that she developed during a period of eleven years (2000-2011). The idea was to mix poetry, "tocapus" (coded textile writing in Quechua language) and ludic visual elements to produce different projects: interactive urban installations (in Cochabamba and La Paz), mappings, analogue projections and audio-visual performances in real time. Some examples of the project Text Textile Code include the following works: Kutikutimuy, a visual and musical experience combined with "tocapu" motifs (Fig. 7b), RIMAYmapping (Modul8), an audio-visual installation that features weaving poetry using textiles, and YAwarniyki (IsadoraCore, Kinetic Sensor), an interactive installation with 100 Led panels and Kinect sensors designed for the Bolivian Cinematheque's facade.

Throughout their artistic careers, Aranda, Muñoz and De Berduccy have shown a great interest in the relationship between art, technology, society and nature. They have underlined the correlation that activities such as painting, engraving and weaving can have with computer programming. In their works, geometric patterns, fibres, cables, 
patterns and threads, they all connect to demystify the distance between ancient art forms and modern technology.

Fig. 7 - Screenshots of a) e-pintura DEMENCIAL (2009-2010) by Yto Aranda; and b) Kutikutimuy (2011) by Sandra De Berduccy.
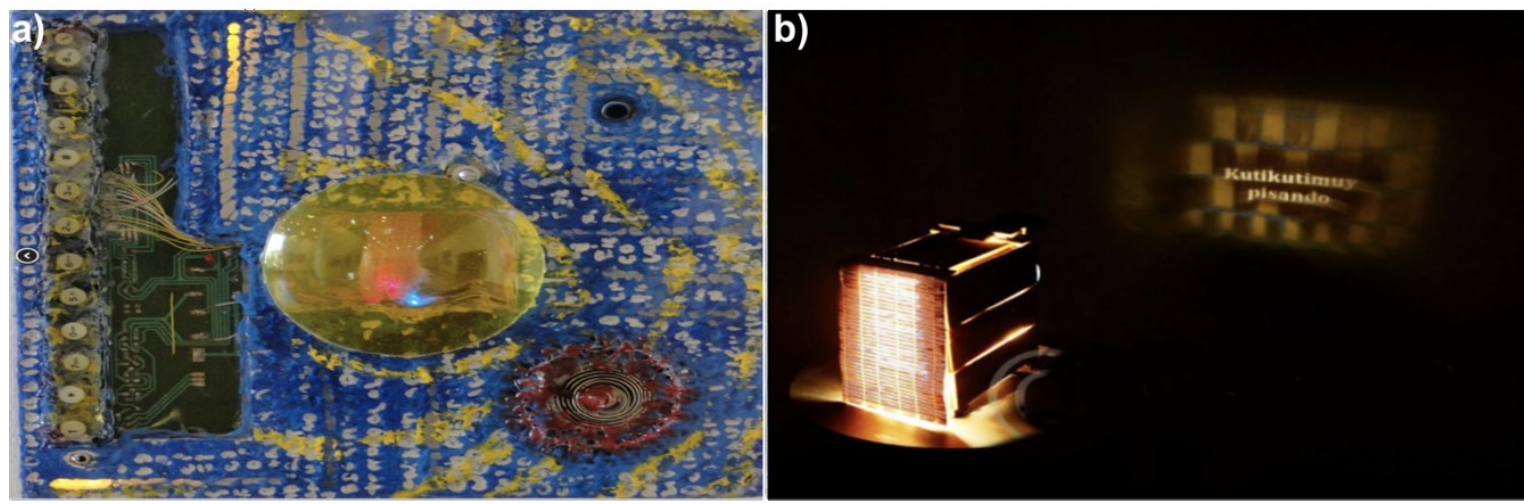

\section{The histogram}

Based on the information gathered together here, taken from the databases mentioned earlier, as well as personal interviews with the artists/writers/programmers themselves, I have created a histogram of 43 digital works created by Latin American women to illustrate the evolution of the field in the region (Fig. 8). As we can see, during the period of 1966-1985, Argentina, Brazil and Chile figure as the first countries where women experimented with mixed media prior to developing born-digital creations. Ana Maria Uribe's visual poetry (Tipoemas, Argentina, 1968-1969) is the first example of experimental literature written by a woman in Latin America of which there is a record. This work is followed by a gap from 1971 to 1975, where, to the best of my knowledge, no works created by women were produced. From 1976 to 1985, we find the works of Lenora de Barros' Poema (Brazil, 1979), Cecilia Vicuña's What is poetry to you? (Chile, 1980) and Damiela Eltit's Lumpérica (Chile, 1983). Although it is clear that these four works are pre-web experimentations of mixed media and literature: visual poetry, a typewriter-human installation, a video-art documentary, a printed book combining literary techniques and multimedia tools, I consider them to be precursors of digital literature in Latin America. 
Fig 8. - Histogram showing the number of e-lit works for 5-year period between 1961 and 2020. The colour indicates the authors' country of birth of the corresponding e-lit works.

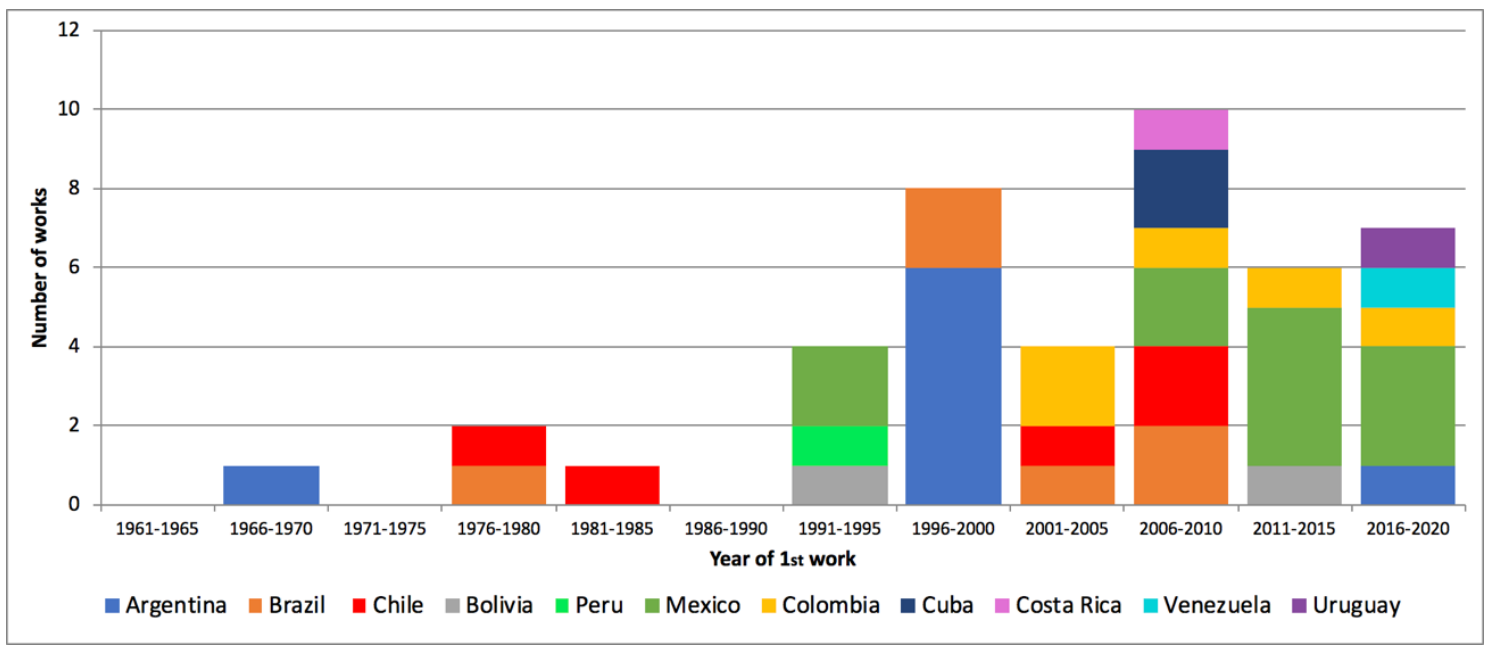

The histogram shows that until the second half of the 90 's, there were only 4 digital works produced, Lucía Grossberger's interactive narrative, Sangre Boliviana (BoliviaUSA, 1994) (MacroMind Director, CD-ROM), Angie Bonino's video installation Schemes (Peru, 1995) (Media 100), Tania Aedo's virtual reality installation Y/O (Mexico, 1995) (Unix, VR) and Grace Quintanilla's video art, Mambo Queen (Mexico, 1995). For the period 1996-2000, there is a large increase of production with a total of 8 digital works. We can identify two significant groups based on the software packages and programming languages used: a) 3 Macromedia Flash works and 5 HTMLs. The first group includes mainly interactive narratives using Macromedia Flash and CDROM storage: Laura Benech's Anónimo (Argentina 1998-1999), Regina Celia Pinto's $O$ Branco e o Negro, Reflexões sobre a Neblina (Brazil, 1999), and Marina Zerbarini's Azul Intenso en un profundo mar (Argentina, 2000); the second group includes webbased hypertextual narratives and kinetic poetry programmed in HTML: Belén Gache's Purpúreas Orquídeas (Argentina, 1996); Ana Maria Uribe's Anipoems (Argentina, 1997), Mariela Yeregui's Ephitelia (Argentina, 1999), Giselle Beiguelman's The Book after the Book (Brazil, 1999), and Gabriela Golder's Postales (Argentina, 2000). In this period, Argentinian women creators are highly represented with a total of six e-lit works, in comparison to other countries such as Brazil or Mexico.

From 2001 to 2010, the appearance of Colombian web-based multimedia narratives mainly developed in Macromedia Flash and Dreamweaver is noticeable: Mónica Montes' Desde Aqui (2001), Carmen Gil Vrolijk's El Alebrije (2004) and Cynthia 
Lawson-Jaramillo, Pompidou from Above (2008); along with Brazilian Vera Biguetti's Shockwake piece Stereoscopy Space (2003), and Chilean Andrea Wolf's Flash piece MemoryFrames (2008). There is also a new group of HTML works that includes Lúcia Leão, Qual és sue sonho? [What is your dream?] (Brazil, 2002), Laura Balboa's you CODE me (Mexico, 2009) and Villeda's LABO (Mexico, 2010). The use of Blogger and WordPress appears for the first time with 3 examples, two in Cuba: Sandra Álvarez's Negra Cubana tenía que ser (2006) and Yoani Sanchez's Generación Y (2007); and one in Costa Rica with Dorelia Barahona's et al. Milagros Sueltos (2007). Exhibitions and art installations also played a significant role in this period featuring works by Eugenia Padro's Hembros (2004-) Lenora de Barros' Calaboca (Brazil, 2006), Adriana Calcahotto's Over and Over, Even (Brazil, 2007) and Yto Aranda's epintura DEMENCIAL, (Chile, 2009-2010).

From 2011 to 2020, the activity in Mexico is quite notorious with 8 e-lit works, due to the opening of a Digital Culture Centre in Mexico City in 2012 and the curation of their own Antología de poesía electrónica in 2018 (including one Argentinian collaborator), as well as the collective development of various e-lit works, mostly web-based multimedia narratives developed using HMTL5, JavaScript and CSS. In this period Colombian writers produced an important second wave of works using HTML5, JavaScript and CSS, including Carolina López's Retratos vivos de mamá (2015) and Alejandra Jaramillo's Mandala (2017). Southern Cone women artists are represented by Uruguayan writer Loren Pose and her first hypertextual narrative in HTML5, Cae (2018). Lastly, installations by Sandra De Berduccy's Text Textile Code (Bolivia, 2011) and Amor Muñoz's Poem Meteor (Mexico, 2015) also figured during this period.

\section{Conclusions}

Electronic literature by Latin American women creators is, as I hope is evident from this overview, an exciting, innovative, diverse and dynamic field of cultural production. Research into early Latin American digital works is a difficult task, especially when tracing creations by women that do not appear in current databases or that have become obsolete. For this reason, a further study on the development of genres of practice of electronic literature in the region is needed. About eighty percent of the 43 women artists included here still create digital works today which shows that certain pioneering 
artists continued to experiment with electronic literature for years. The fact that Argentina, Brazil and Chile have had a significant impact on the development of the field since the mid 60's and until the late 80's explains the high presence of these countries in later years. The interviews have shed light on the first women translators of electronic literature in Latin America (English into Portuguese) and on the first works written in languages other than Spanish and Portuguese (e.g. English and French). This highlights the impact of migration not only at a level of aesthetic creation but also at the level of availability of technological tools (software packages, creative platforms, programming languages and internet access) considering that some early works were developed during artistic residencies in North America and Europe. I am aware that the selection of 43 women artists does not cover all the electronic literary works produced by Latin American women in the periods of reference. For this reason, this overview acts as a first attempt towards documenting the contribution of Latin American women to electronic literature and an invitation to others to fill this gap.

\section{REFERENCES}

\section{Critical Works Cited}

ENGBERG, Maria. "Aesthetics of Visual Noise in Digital Literary Arts." University of Jyväskylä, Cybertext Yearbook 2010, edited by Raine Koskimaa and Markku Eskelinen, 2010, http://cybertext.hum.jyu.fi/index.php?browsebook=7.

HENKEN, Ted. 'En Busca de La 'Generación Y': Yoani Sánchez, La Blogosfera Emergente y El Periodismo Ciudadano de La Cuba de Hoy.” Buena Vista Social Blog: Internet, y Libertad de Expresión En Cuba, edited by Beatriz Calvo Peña, Advana Vieja, 2010, pp. 201-42.

KOZAK, Claudia. "Comunidades experimentales y literatura digital en Latinoamérica." Virtualis, vol. 9, no. 17, 17, Oct. 2018, pp. 9-35.

https:/www.revistavirtualis.mx/index.php/virtualis/article/view/272

MENCÍA, María, editor. \#WomenTechLit. West Virginia University Press. 2017. 
NEUSTADT, Robert. (Con)Fusing Signs and Postmodern Positions: Spanish American Performance, Experimental Writing, and the Critique of Political Confusion. Garland Publishing, INC. 1999.

PITMAN, Thea. "Latin American Electronic Literature Created by Women / La literatura electrónica latinoamericana creada por mujeres," Latin American Literature Today, 10, dossier "Digital Literature," ed. by Scott Weintraub, (2019). http://www.latinamericanliteraturetoday.org/en/2019/may/latin-american-electronicliterature-created-women-thea-pitman

RETTBERG, Scott. Electronic Literature. Polity Press. 2019

SIERRA, Judith. "Afro-Cuban Cyberfeminism: Love/Sexual Revolution in Sandra Álvarez Ramírez’s Blogging.” Latin American Research Review, vol. 53, no. 2, 2018, pp. 330-43.

TAYLOR, Claire. Electronic Literature in Latin America: From text to hypertext. Palgrave McMillan. 2019.

WEINTRAUB, Scott. Latin American Technopoetics: Scientific Explorations in New Media. Routledge, 2018.

ZERBARINI, Marina. Radiografía Del Net.Art Latino. Vitalidad Creativa En Riego de Extinción. Editorial Dunken, 2014.

\section{Creative Works Cited}

AEDO, Tania. Bodies in Progress. 1997.

---. Y/O. 1995.

ÁLVAREZ, Sandra. Negra Cubana Tenía Que Ser. 2006, https://negracubanateniaqueser.com.

ARANDA, Yto. E-Pintura DEMENCIAL. 2009, http://yto.cl/demente/.

---. $(((K O))) \varepsilon>-<\left(\left(a Q u a \_\right.\right.$esfera $\left.)\right)>-<3.2017$, http://yto.cl/ko/.

BALBOA, Laura. You CODE Me. 2009, http://youcode.me.

BARAHONA, Dorelia, et al. Milagros sueltos. 2007, https://ccecr.wordpress.com/2007/07/30/milagros-sueltos-primera-entrega/. 
BEIGUELMAN, Giselle. //**Code_UP. 2004, http://netescopio.meiac.es/proyecto/0015/code_up/web/english/index.htm.

---. Leste o Leste? 2002, http://www.desvirtual.com/public-art-sp-2002.

---. Poétrica. 2003, http://desvirtual.com/poetrica.

---. The Book after the Book. 1999, http://www.desvirtual.com/thebook/.

---. The QR Poem. 2010,

http://www.ubu.com/contemp/beiguelman/beiguelman_giselle_theqrpoem_2010.png.

BEIGUELMAN, Giselle, and Helga STEIN. Code Movie 1. 2004, http://collection.eliterature.org/1/works/beiguelman_code_movie_1.html.

BENECH, Laura. Anónimo. 1998, http://obraas.net/.

BIGUETTI, Vera Sylvia.Gr@fite. 2004, https://www.behance.net/gallery/705169/GRFITE.

---. Objeto Livro Jogo. 2004, http://www.artzero.net/objeto/index.htm.

---. Stereoscopy Space. 2003, https://www.behance.net/gallery/703785/StereoscopySpace.

BOLUK, Stephanie, et al., editors. The Electronic Literature Collection, Volume Three. Electronic Literature Organization, 2016, http://collection.eliterature.org/3.

BONINO, Angie. Schemes. 1995.

---. Retrospective of Toxic Plastic Stuff. 1998.

---. Mr. President. 1999. https://vimeo.com/20323466

BORRÀS, Laura, et al., editors. The Electronic Literature Collection, Volume Two. Electronic Literature Organization, 2011, http://collection.eliterature.org/2.

CALCANHOTTO, Adriana. Over and Over, Even. 2007, https:/elmcip.net/creativework/over-and-over-even.

---. Augusto. 2011, https://erratica.com.br/opus/104/adriana.html

CAZÓN, Romina. La poesía es una diosa. 2018, http://poesiaelectronica.centroculturadigital.mx/rominacazon. 
CORTÉS, Nadia. Filiaciones Textuales. 2018,

http://poesiaelectronica.centroculturadigital.mx/nadiacortes/filiaciones-textuales.

DE BARROS, Lenora. Poema. 1979, https://awarewomenartists.com/en/artiste/lenorade-barros/; https://enciclopedia.itaucultural.org.br/pessoa109502/lenora-de-barros.

---. See me. 2003, http://www.nomuque.net/arteria8/home.html

---. Calaboca. 2006, https://vimeo.com/40758774.

DE BERDUCCY, Sandra. Texto Textil Código. 2011, https://sandradeberduccy.com/projects/engtexttc/.

DE LA TORRE, Yolanda, et al. Umbrales. 2014, http://www.umbrales.mx.

ELTIT, Diamela. Lumpérica. Las Ediciones del Ornitorrinco, 1983.

GACHE, Belén, et al. Fin Del Mundo El Arte Actual Desde Argentina. 2009 1995, http://www.findelmundo.com.ar/intro21.htm.

---. Góngora Wordtoys (Soledades). 2011, http://belengache.net/gongorawordtoys/gongorawordtoys.html.

---. Mariposa-Libro. 1999, http://www.findelmundo.com.ar/mariplib/intro.htm.

---. Purpúreas orquídeas, poemas cíclicos. 1996, http://www.findelmundo.com.ar/orquideas/Default.htm.

---. Wordtoys. 2006, http://www.findelmundo.com.ar/wordtoys.

GATTASS, Luciana, editor. Brazilian Electronic Literature Collection. ELMCIP, 2012, https://elmcip.net/research-collection/brazilian-electronic-literature-collection.

GIL, Carmen. El alebrije. 2004, http://www.elalebrije.org/.

GOLDER, Gabriela. Postales. 1999, http://postal.free.fr/index1.html.

GROSSBERGER, Lucía. Sangre Boliviana. 1994, http://www.cyber-chica.com/sangreboliviana.html.

HAYLES, Katherine, et al., editors. The Electronic Literature Collection, Volume One. Electronic Literature Organization, 2006, http://collection.eliterature.org/1.

JARAMILLO, Alejandra. Mandala. 2017, https://www.novelamandala.com/. 
LAWSON, Cynthia. 28 days. 2007, http://www.cynthialawson.com/site/?p=210.

---. Pompidou from Above. 2008, http://www.cynthialawson.com/site/?p=212.

---. Voice Diaries. 2009, http://www.cynthialawson.com/site/?p=208.

LEÃO, Lúcia. Hermenetka. 2005, https://elmcip.net/creative-work/plural-maps-lostsao-paulo.

---. Plural maps; lost in São Paulo. 2002, https://elmcip.net/creative-work/plural-mapslost-sao-paulo.

---. Qual é o seu sonho? 2002, https://elmcip.net/creative-work/what-your-dream.

LÓPEZ, Jacalyn. Glasshouses: A Tour of American Assimilation from a MexicanAmerican Perspective. http://artelunasol.com/GHstatement.html.

LÓPEZ, Carolina. Retratos vivos de mamá. 2015, https://www.retratosvivosdemama.co/.

MEDINA, Ana. Seis minutos para tomar el T. 2018, http://poesiaelectronica.centroculturadigital.mx/anamedina.

MENCÍA, María. El Winnipeg. El poema que cruzó el Atlántico. 2015, http://winnipeg.mariamencia.com/?lang=es\#winnipeg.

---. Mujeres voces invisibles. 2020, https://www.voces-invisibles.com/.

MONTES, Mónica. Desde Aquí. 2001, https://webs.ucm.es/info/especulo/hipertul/desdeaqui/index.htm.

MUÑOZ, Amor. Data Digital Code Red. 2019, https://amormunoz.net/2019/11/15/datadigital-codes/.

---. Poem Meteor. 2015, https://amormunoz.net/2019/11/13/poem-meteor/.

PINTO, Regina Célia. Museu do essencial e do alem disso. 2002, https://elorepository.org/museum-of-the-essential/.

---. O Branco e o Negro, Reflexões Sobre a Neblina. 1999, https://elorepository.org/museum-of-the-essential/cybercircus/mainintro.htm.

---. Viewing Axolotls. 2004, https://elo-repository.org/museum-of-theessential/arteonline4/definitionenglish.htm. 
POSE, Loren. Cae. 2018, http://salta.atwebpages.com/\#cae.

---. Palabroscopio. 2019, http://palabroscopio.atwebpages.com/.

PRADO, Eugenia. Hembros: asedios de lo post humano. 2006, http://hembroseugeniaprado.blogspot.com/.

---. "Deambulo por las redes porque escribir es político y para mí lo micro funciona" Interview with Carolina Gainza. http://culturadigitalchile.cl/wpcontent/uploads/2017/03/Entrevista-Eugenia-Prado.pdf

QUINTANILLA, Grace. Bits de Memoria. 1999, https://vimeo.com/87221304.

---. Mambo Queen. 1995, https://vimeo.com/7089282.

---. Viceversa. 1998, https://vimeo.com/88794144.

REYNOSA, Minerva. Mammut. 2015, https://vimeo.com/135401429.

RODRÍGUEZ, Xitlálitl, et al. Catnip. 2015, http://catnip.centroculturadigital.mx.

SANCHÉZ, Yoani. Generación Y. 2007, http://desdecuba.com/generaciony.

STRICKLAND, Stephanie, et al. Slippingglimpse. 2007, http://slippingglimpse.org.

STRICKLAND, Stephanie, and Cynthia Lawson Jaramillo. V : Vniverse. 2002, http://www.stephaniestrickland.com/vniverse.

URIBE, Ana María. Anipoems. 1997, http://www.vispo.com/uribe/index.html.

---. Typoems. 1968, http://www.vispo.com/uribe/index.html.

VICUÑA, Cecilia. Paracas. 1983, hhttp://www.ceciliavicuna.com/films/2016/2/22/paracas-1983.

---. What Is Poetry for You? 1980, http://www.ceciliavicuna.com/films/2016/4/6/whatis-poetry-to-you.

VILLANUEVA, Carolina. De ti a mi no hay distancia. 2018, http:/carolinavillanuevalucero.net/net/mientrasescribo/.

VILLEDA, Karen. LABO/Laboratorio de ciberpoesía. 2010.

http://www.poetronica.net/LABO/index.html 
---.Sorjuanizate. 2016, http://www.poetronica.net/sorjuanizate.html.

VILLEDA, Karen, and Denise Audirac. POETtuitéame. 2014, http://www.poetronica.net/poetuiteame.html.

WOLF, Andrea. memoryFrames. 2008,

http://www.andreawolf.me/artwork/2014/5/13/jkw.

YEREGUI, Mariela. Ephitelia. 1999, https://vimeo.com/231800139.

ZERBARINI, Marina. Azul Intenso En Un Profundo Mar. 2000, https://www.marinazerbarini.com.ar/sitezerbarini.html.

---. Eveline: fragmentos de una respuesta. 2004, https://www.marinazerbarini.com.ar/sitezerbarini.html.

---. Shadows. 2000, https://www.marina-zerbarini.com.ar/sitezerbarini.html.

---. The Dream Is Gone. 2001, https://www.marina-zerbarini.com.ar/sitezerbarini.html.

ZALBIDEA, Maya, editor. Spanish Language Electronic Literature. ELMCIP, 2014, https://elmcip.net/research-collection/spanish-language-electronic-literature.

\section{Other Resources}

Antologías Itaú. (2011-) https://www.antologiasitau.org/.

Antología de poesía electrónica. (2018)

http://editorial.centroculturadigital.mx/pieza/antologia-de-poesia-electronica.

Atlas de Literatura Digital Brasileira (2019-). http://www.atlasldigital.ufscar.br/

Ciberia Project (2014-) http://www.ciberiaproject.com/

Cultura Digital Chile Project (2016). http://culturadigitalchile.cl

ELMCIP Electronic Literature Knowledge Base (2010-).

http://elmcip.net/knowledgebase. 


\section{NOTAS DE AUTORIA}

Nohelia Meza (n.meza@leeds.ac.uk) Postdoctoral Researcher University of Leeds, UK.

PhD Pompeu Fabra University, Barcelona.

\section{Como citar este artigo de acordo com as normas da revista?}

MEZA, Nohelia. Women creators of Latin American electronic literature: a geographical overview. Texto Digital, Florianópolis, v. 16, n. 1, p. 183-216, 2020.

\section{Agradecimentos}

This article has developed out of a much shorter piece written by Thea Pitman and published as "Latin American Electronic Literature Created by Women" in Latin American Literature Today. While the vast majority of the text is my own, I acknowledge and use Thea's work in places with kind permission. I also want to thank the artists for taking time and effort in answering my questions during the interviews, without their help this paper would not have been possible.

\section{Contribuição de autoria}

Não se aplica.

\section{Financiamento}

Postdoctoral Fellowship CONACYT-México: 2019-000029-01EXTV-00115

\section{Consentimento de uso de imagem}

Não se aplica.

\section{Aprovação de comitê de ética em pesquisa}

Não se aplica.

\section{Licença de uso}

Este artigo está licenciado sob a Licença Creative Commons CC-BY. Com essa licença você pode compartilhar, adaptar, criar para qualquer fim, desde que atribua a autoria da obra.

\section{Histórico}

Recebido em: 13/05/2020.

Aprovado em: 09/07/2020. 